\title{
Management of intracerebral hemorrhage - use of statins
}

\author{
This article was published in the following Dove Press journal: \\ Vascular Health and Risk Management \\ 18 April 2016 \\ Number of times this article has been viewed
}

\section{Edward T Van Matre \\ Deb S Sherman ${ }^{2}$ \\ Tyree H Kiser ${ }^{1,2}$}

'Department of Clinical Pharmacy, University of Colorado Skaggs School of Pharmacy and Pharmaceutical Sciences, ${ }^{2}$ Department of Pharmacy, University of Colorado Hospital, Aurora, CO, USA
Correspondence: Tyree H Kiser Department of Clinical Pharmacy, University of Colorado Skaggs School of Pharmacy and Pharmaceutical Sciences, Mail Stop C238, I 2850 E. Montview Blvd, Room V20-1 226, University of Colorado Anschutz Medical Campus Aurora, CO 80045 , USA

Tel +l 3037242883

Fax +l 3037240979

Email ty.kiser@ucdenver.edu

\begin{abstract}
Intracerebral hemorrhage (ICH) is a neurologic injury resulting in significant morbidity and mortality. Statins play a significant role in primary and secondary prevention of cardiovascular and cerebrovascular ischemic events. Despite clear benefits of statins in ischemic stroke, post hoc analyses of some studies suggest there may be a link between statin therapy and development of ICH. Direct pharmacologic effects of decreased serum levels of total cholesterol and low-density lipoproteins in conjunction with pleiotropic effects are thought to be linked to this possible increase in ICH risk. In the face of the potential of statins to increase the risk of $\mathrm{ICH}$, recent evidence suggests that statins may also have beneficial effects on patient outcomes when continued or initiated following an ICH. This discordance in findings and the overall lack of well-designed prospective clinical trials increase the complexity of clinical decision making when utilizing statin therapy in patients with, or at risk for, $\mathrm{ICH}$. This review evaluates the pharmacologic effects of statin therapy and describes how these effects translate to both risks and benefits in ICH. The current literature regarding the effects of statin therapy on clinical outcomes in ICH is evaluated to help guide clinicians with decisions regarding initiation, continuation, or discontinuation of statin therapy in patients with $\mathrm{ICH}$.
\end{abstract}

Keywords: intracerebral hemorrhage, statin pharmacology, intracranial hemorrhage, 3-hydroxy3-methylglutaryl coenzyme A reductase inhibitors, pleiotropic effects

\section{Introduction}

Intracerebral hemorrhage ( $\mathrm{ICH})$ accounts for $10 \%-20 \%$ of all strokes worldwide. ${ }^{1}$ The overall global incidence of ICH is estimated at 24.6 per 100,000 person-years. ${ }^{2}$ Significant risk factors for ICH include hypertension, amyloid angiopathy, and older age. ${ }^{3}$ Other risk factors include male sex, smoking, diabetes, alcohol intake, cocaine hydrochloride use, and use of antiplatelet or anticoagulant medications. ${ }^{4-6}$ Compounding risk factors are likely to increase the risk of a patient suffering from ICH. ICH commonly occurs in the cerebral lobes, basal ganglia, thalamus, brain stem, and cerebellum. Hemorrhage results from rupture of small penetrating arteries originating from basilar arteries or the anterior, middle, or posterior cerebral arteries. ICH carries a significant mortality risk with 1-year survival estimated at 46\% and 5-year survival estimated at $29 \%{ }^{7}$ Given the high degree of morbidity and mortality associated with $\mathrm{ICH}$, evaluation of therapies that may have neuroprotective effects is of increasing interest to clinicians.

The 3-hydroxy-3-methylglutaryl coenzyme A (HMG-CoA) reductase inhibitors, commonly known as statins, provide cholesterol-lowering effects through competitive, reversible inhibition of HMG-CoA reductase, the rate limiting step in cholesterol 
biosynthesis. ${ }^{8,9}$ This mechanism is the primary driver for the observed reduction in cardiovascular events and ischemic stroke in patients with coronary artery disease. ${ }^{10}$ In addition to their cholesterol-lowering effects, statins also have pleotropic effects, including anti-inflammatory, antithrombotic, antioxidative, and neuroprotective effects that have all been demonstrated in animal models and/or patients. ${ }^{11,12}$ The primary aim of this review is to evaluate the pharmacologic effects and outcomes associated with statin use in relation to ICH.

\section{Literature review methodology}

Studies were identified by performing a MEDLINE and PubMed search using the following terms: (statin* OR 3-hydroxy-3-methylglutaryl coenzyme A reductase inhibitors OR HMG-CoA) AND (intracerebral hemorrhage OR cerebral hemorrhage). Studies published after October 31, 2015 and those published in languages other than English were not included. Studies meeting criteria were evaluated by the authors for relevance and inclusion.

\section{Statin pharmacologic properties}

Although all statins share the same primary mechanism of action through the competitive, reversible inhibition of HMG-CoA reductase, there are many differences within this class of drugs. There are seven statins currently available in the USA: atorvastatin, fluvastatin, lovastatin, pitavastatin, pravastatin, rosuvastatin, and simvastatin. Statins have a high bioavailability and are currently only available in oral formulations. Comparison of pharmacologic properties among available statin medications can be found in Table 1 . The observed differences in drug pharmacology may ultimately impact the possible risks and benefits of statin therapy in ICH. ${ }^{8,9,13}$ Statin penetration across the blood-brain barrier and into the cerebral cortex is directly related to the lipophilic properties of each statin. ${ }^{14}$ A murine model evaluated simvastatin, lovastatin, and pravastatin concentrations within the cerebral cortex. This model showed higher concentrations of simvastatin and then lovastatin followed by pravastatin. These results are consistent with the partition coefficient $(\log \mathrm{D})$ results in Table 1 with simvastatin and lovastatin being the most lipophilic statins. ${ }^{15,16}$ In addition to the pharmacokinetic properties of statins, the relative potency of low-density lipoprotein (LDL) reduction should also be considered. Two landmark trials evaluated the relative potency of statin therapies. Potency was determined by percent change in LDL from baseline. Rosuvastatin was found to be the most potent followed by atorvastatin, pitavastatin, simvastatin, lovastatin, pravastatin, and finally fluvastatin. . $^{8,17,18}$

While statin discontinuation rates due to side effects in clinical trials have been found to be similar to placebo, statins do carry clinical risks to be considered prior to initiating therapy. Within the general population, asymptomatic elevations in liver enzymes have been reported in $1 \%$ of patients on statin therapy and are dose-related. Spontaneous resolution occurs with discontinuation of the statin. Myopathy has also been reported with an occurrence rate of $<0.1 \%$. If untreated, myopathy can progress to rhabdomyolysis leading to end-organ damage and death. ${ }^{19}$ Despite a lack of clinical trials to evaluate the safety profile of statin therapy in patients with $\mathrm{ICH}$, risks for side effects can be extrapolated from the neurocritically ill and general critically ill populations. A recent prospective study evaluated 21 days of simvastatin therapy following subarachnoid hemorrhage in 803 patients with aneurysmal subarachnoid hemorrhage. The study results demonstrated no difference in increased liver function tests or rhabdomyolysis compared to placebo. ${ }^{20}$ Approximately $25 \%-36 \%$ of patients admitted to the intensive care unit for $\geq 7$ days develop intensive care unit-acquired weakness based on clinical exam. The incidence has been reported as high as $57 \%$ when neurophysiologic testing was performed.

Table I Pharmacokinetic properties of statins

\begin{tabular}{llllllll}
\hline $\begin{array}{l}\text { Pharmacologic } \\
\text { properties }\end{array}$ & Atorvastatin & Fluvastatin & Lovastatin & Pitavastatin & Pravastatin & Rosuvastatin & Simvastatin \\
\hline Prodrug & No & No & Yes & No & No & No & Yes \\
Half-life (hours) & 14 & 2.3 & 3 & 12 & $1.3-2.7$ & 29 & 3 \\
logD* pH: 7.4 & I.53 & 1.75 & 2.59 & 1.50 & -0.47 & -0.25 & 2.44 \\
Lipophilicity & Lipophilic & Lipophilic & Lipophilic & Lipophilic & Hydrophilic & Hydrophilic & Lipophilic \\
CYP substrate & 3 A4 & 2 C9 & 3 A4 & Glucuronidation & Sulfation & Unchanged & 3 A44 \\
Active metabolites & Active & Inactive & Active & Active (minor) & Inactive & Active (minimal) & Active \\
Protein binding (\%) & 98 & $>98$ & $>95$ & 96 & 50 & 90 & $95-98$ \\
Renal excretion & $<2$ & 6 & 10 & 2 & 20 & 10 & 13 \\
Fecal excretion & $>98$ & 93 & 83 & 79 & 70 & 90 & 60 \\
\hline
\end{tabular}

Notes: *Log D - partition coefficient - used to measure a medication's lipophilicity. Higher numbers indicate increased lipophilicity. Data from Schachter, McFarland et al and Corsini et al..$^{8,9,13}$

Abbreviation: CYP, cytochrome P450. 
Myopathies in critical illness have been described in up to $96 \%$ of patients with intensive care unit-acquired weakness. ${ }^{21-23}$ Based upon these results, patients with $\mathrm{ICH}$ are likely to be at high risk for myopathy due to immobility, extended mechanical ventilation, and exposure to corticosteroids and neuromuscular blocking agents throughout their care. $^{24}$

Drug interactions must also be considered in patients taking or initiating statin therapy. Most statins are metabolized via the cytochrome P450 enzymes. Careful consideration must be given to these interactions as inducers and inhibitors can decrease efficacy and increase risk for toxicity, respectively. ${ }^{25}$ If discontinuation of the interacting medication is not possible, then choosing a statin with a lower risk for drug interactions is likely prudent.

\section{Effects of statin use on clinical outcomes}

The Stroke Prevention by Aggressive Reduction in Cholesterol Levels (SPARCL) study evaluated high dose (80 mg) atorvastatin compared to placebo for incidence of nonfatal and fatal stroke in patients with a history of transient ischemic attack or stroke in the previous 6 months (Table 2). The study showed a 5-year absolute risk reduction in nonfatal and fatal stroke of $2.2 \%(P=0.03)$ for patients taking high dose atorvastatin. A post hoc analysis of treatment effect on type of stroke showed a significant increase in hemorrhagic stroke in the high dose atorvastatin group. ${ }^{26}$ Further evaluation of this cohort found no difference in severity or outcomes when comparing patients in both arms suffering from hemorrhagic stroke. ${ }^{27}$

Following the SPARCL trial, three major questions emerged regarding the relationship between statin therapy and ICH: 1) does statin therapy place patients at increased risk for $\mathrm{ICH}$; 2) does initiation of statin therapy following ICH improve outcomes; and 3) should patients currently receiving statin therapy have treatment discontinued immediately following ICH? Various studies and meta-analyses have attempted to answer these questions with mixed results (Table 2).

\section{Does statin therapy place patients at increased risk for $\mathrm{ICH}$ ?}

A recent large population-based case-control study from Sweden, including ICH cases $(n=7,696)$ and matched stroke-free controls $(n=14,670)$, evaluated the association between chronic statin therapy and ICH. Patients' medication history was included for 6 months prior to evaluation. No difference in risk for development of ICH in the unadjusted model was found. In the adjusted model, statins were found to be protective against $\mathrm{ICH}$ for concomitant drug use and comorbid diseases (odds ratio [OR] $=0.68$, $95 \%$ confidence interval [CI]: 0.63-0.74). ${ }^{28}$ A follow-up retrospective analysis showed chronic statin users had less severe ICH. ${ }^{29}$ Several well controlled meta-analyses reported no difference in rates of $\mathrm{ICH}$ in patients receiving statin therapy compared to no statin therapy. ${ }^{30-32}$ Pre-ICH therapy was associated with increased probability of positive functional outcomes, based on modified Rankin Scale (mRS) score and Glasgow Outcome Scale. ${ }^{31}$ A meta-analysis performed by McKinney et al included 31 randomized control trials with 182,803 patients, including patients from the SPARCL study. Results demonstrated no significant difference in incidence of ICH observed in the active statin treatment group. The meta-analysis also showed no relationship between achieved LDL level or the degree of LDL reduction from baseline and risk of $\mathrm{ICH}$. The analysis did find significant reductions in total stroke and all-cause mortality in the active statin therapy group. ${ }^{33}$ Current guidelines do not recommend avoiding statin therapy due to a potential risk of $\mathrm{ICH}^{34}$

\section{Does initiation of statin therapy following $\mathrm{ICH}$ improve outcomes?}

There are currently no prospective randomized trials that are adequately powered to evaluate the impact of starting statin therapy on major clinical outcomes following $\mathrm{ICH}$. Several retrospective meta-analyses and database studies have demonstrated improved mortality and functional outcomes with statin therapy following ICH (Table 2). These outcomes are notable as the outcomes remained significant after adjustment for prehospital statin use within their statistical evaluations. ${ }^{31,35,36}$ Unfortunately, none of the analyses clearly defined the initiation time frame of statin therapy following $\mathrm{ICH}$, so the window of opportunity for initiation post-ICH requires further refinement.

The role of initiating statin therapy following ICH in statin naïve patients is not well defined. Two retrospective database reviews evaluated patients with no prehospital statin therapy. The first database review $(n=8,332)$ demonstrated that early statin use did not increase the risk of recurrent ICH (hazard ratio: $1.044,95 \%$ CI: 0.812-1.341). All-cause mortality was significantly lower in patients receiving early statin therapy (hazard ratio: $0.742,95 \% \mathrm{CI}: 0.598-0.919) .{ }^{37}$ The second database review $(n=3,218)$ evaluated 3- and 12-month functional outcomes and mortality. Functional outcomes were improved at 3 months ( $\mathrm{OR}=2.24,95 \% \mathrm{CI}: 1.49-3.36)$ and at 1 year $(\mathrm{OR}$ $=2.04,95 \%$ CI: $1.37-3.06$ ) in patients receiving statin therapy. Additionally, patients receiving statins had a lower mortality rate at 3 months $(\mathrm{OR}=0.44,95 \% \mathrm{CI}$ : $0.22-0.87)$ and 1 year $(\mathrm{OR}=0.49,95 \% \mathrm{CI}: 0.27-0.86) .{ }^{38}$ Although the data are not 
Table 2 Studies evaluating statin effects on clinical outcomes in $\mathrm{ICH}$

\begin{tabular}{|c|c|c|c|c|c|}
\hline Study & Study design & $\begin{array}{l}\text { Number } \\
\text { of } \\
\text { patients }\end{array}$ & Statin use & $\begin{array}{l}\text { Outcomes } \\
\text { measured }\end{array}$ & Results \\
\hline $\begin{array}{l}\text { Flint } \\
\text { et } \mathrm{al}^{35}\end{array}$ & $\begin{array}{l}\text { Retrospective } \\
\text { cohort }\end{array}$ & 3,481 & $\begin{array}{l}\text { Statin use prior to } \\
\text { admission for } \mathrm{ICH} \text { and } \\
\text { statin use in-patient } \\
\text { following } \mathrm{ICH}\end{array}$ & $\begin{array}{l}\text { 30-day survival and } \\
\text { discharge to home or } \\
\text { rehabilitation facility }\end{array}$ & $\begin{array}{l}\text { - In-patient statin users were more likely to be } \\
\text { alive at } 30 \text { days OR }=4.25(95 \% \mathrm{Cl}: 3.46-5.23) \\
\text { - In-patient statin users were more likely to be } \\
\text { discharged to home or acute rehabilitation } \\
\text { facility OR }=2.57(95 \% \mathrm{Cl}: 2.16-3.06) \\
\text { - Discontinuation of outpatient statin therapy } \\
\text { resulted in decreased } 30 \text {-day survival OR } \\
=0.16(95 \% \mathrm{Cl}: 0.12-0.2 \mathrm{I}) \text { and decreased } \\
\text { favorable discharge } \\
\text { OR }=0.26(95 \% \mathrm{Cl}: 0.20-0.35)\end{array}$ \\
\hline $\begin{array}{l}\text { Perez } \\
\text { et } \mathrm{al}^{32}\end{array}$ & Meta-analysis & 17 trials & $\begin{array}{l}\text { Statin use prior to } \mathrm{ICH} \\
\text { and discontinuation of } \\
\text { statin following } \mathrm{ICH}\end{array}$ & $\begin{array}{l}\text { Morbidity and } \\
\text { mortality; functional } \\
\text { status }\end{array}$ & $\begin{array}{l}\text { - Overall OR for mortality } \leq 3 \text { months was } \\
0.7 \mathrm{I}(95 \% \mathrm{Cl}: 0.55-0.98) \text { favoring statin users } \\
\text { - Overall OR for mortality } \geq 6 \text { months } 0.7 \mathrm{I} \\
\text { ( } 95 \% \mathrm{Cl}: 0.43-\mathrm{I} .15 \text { ) } \\
\text { - Risk reduction for continuation of statin post- } \\
\text { ICH } 0.14 \text { ( } 95 \% \mathrm{Cl}: 0.10-0.20) \\
\text { - No difference in functional outcomes with } \\
\text { continuation of statin post-ICH }\end{array}$ \\
\hline $\begin{array}{l}\text { SPARCL } \\
\text { trial }^{26,27}\end{array}$ & $\mathrm{RCT}$ & 4,731 & $\begin{array}{l}\text { Patients with stroke or } \\
\text { TIA randomized to } 80 \mathrm{mg} \\
\text { atorvastatin vs placebo }\end{array}$ & $\begin{array}{l}\text { Post hoc analysis } \\
\text { based on type of } \\
\text { stroke occurrence and } \\
\text { outcomes based on } \\
\text { stroke type }\end{array}$ & $\begin{array}{l}\text { - Hemorrhagic stroke treatment hazard ratio } \\
\text { I.66 ( } 95 \% \text { CI: I.08-2.55) } \\
\text { - No difference in patients with hemorrhagic } \\
\text { stroke in NIHSS, mRS, and disability between } \\
\text { atorvastatin and placebo groups }\end{array}$ \\
\hline $\begin{array}{l}\text { McKinney } \\
\text { et } \mathrm{al}^{33}\end{array}$ & Meta-analysis & $\begin{array}{l}182,803 \\
\text { (3I trials) }\end{array}$ & $\begin{array}{l}\text { Patients receiving statin } \\
\text { therapy compared to } \\
\text { control; > I8 years old, } \\
\text { RCT design, blinded } \\
\text { outcomes, recoded data } \\
\text { on hemorrhagic stroke } \\
\text { or ICH }\end{array}$ & $\begin{array}{l}\text { Incidence of ICH; } \\
\text { total stroke; all-cause } \\
\text { mortality }\end{array}$ & $\begin{array}{l}\text { - ICH OR }=\text { I. } .08(95 \% \mathrm{Cl}: 0.88-\mathrm{I} .32) \\
\text { - All stroke OR }=0.84(95 \% \mathrm{Cl}: 0.78-0.9 \mathrm{I}) \\
\text { - All-cause mortality OR }=0.92(95 \% \mathrm{Cl}: \\
0.87-0.96)\end{array}$ \\
\hline $\begin{array}{l}\text { Jung } \\
\text { et } \mathrm{al}^{31}\end{array}$ & Meta-analysis & 16 trials & $\begin{array}{l}\text { I } 2 \text { pre-ICH statin use; } \\
\text { five in-hospital statin use; } \\
\text { three statin withdraw }\end{array}$ & $\begin{array}{l}\text { Mortality and } \\
\text { functional outcomes }\end{array}$ & 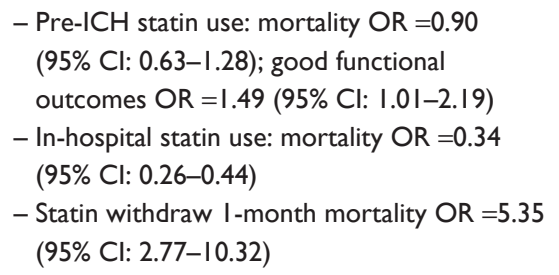 \\
\hline $\begin{array}{l}\text { Hackam } \\
\text { et } \mathbf{a}^{30}\end{array}$ & Meta-analysis & $\begin{array}{l}248,391 \\
\text { (42 trials) }\end{array}$ & $\begin{array}{l}23 \text { RCT } \\
19 \text { observational }\end{array}$ & $\begin{array}{l}\text { RR for development } \\
\text { of } \mathrm{ICH}\end{array}$ & $\begin{array}{l}\text { - Randomized trials RR for development of ICH } \\
\text { is I.I0 ( } 95 \% \mathrm{Cl}: 0.86-1.36) \text { and total stroke } \\
0.85(95 \% \mathrm{Cl}: 0.78-0.93) \\
\text { - Observation studies RR for development of } \\
\text { ICH } 0.94(95 \% \mathrm{Cl}: 0.8 \mathrm{I}-\mathrm{I} .10) \\
\text { - Studies with cerebrovascular disease } \\
\text { populations OR }=\mathrm{I} .03(95 \% \mathrm{Cl}: 0.82-\mathrm{I} .30)\end{array}$ \\
\hline $\begin{array}{l}\text { Winkler } \\
\text { et } \mathrm{al}^{36}\end{array}$ & $\begin{array}{l}\text { Retrospective } \\
\text { database analysis }\end{array}$ & $\begin{array}{l}562 \\
\text { patients }\end{array}$ & $\begin{array}{l}\text { Statin use prior to } \\
\text { admission or initiation } \\
\text { with } 72 \text { hours of } \mathrm{ICH}\end{array}$ & $\begin{array}{l}\text { Risk factors for poor } \\
\text { functional recovery } \\
\text { at } 12 \text { months and in- } \\
\text { patient and } 12 \text {-month } \\
\text { mortality }\end{array}$ & 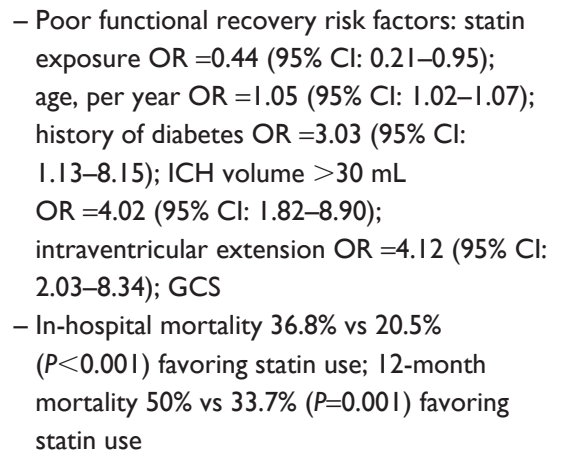 \\
\hline
\end{tabular}


Table 2 (Continued)

\begin{tabular}{|c|c|c|c|c|c|}
\hline Study & Study design & $\begin{array}{l}\text { Number } \\
\text { of } \\
\text { patients }\end{array}$ & Statin use & $\begin{array}{l}\text { Outcomes } \\
\text { measured }\end{array}$ & Results \\
\hline $\begin{array}{l}\text { Pan } \\
\text { et } \mathrm{al}^{38}\end{array}$ & $\begin{array}{l}\text { Retrospective } \\
\text { database analysis }\end{array}$ & $\begin{array}{l}3,218 \\
\text { patients }\end{array}$ & $\begin{array}{l}\text { Statin initiated during } \\
\text { hospitalization }\end{array}$ & $\begin{array}{l}\text { Functional outcomes } \\
\text { (mRS) at } 3 \text { and } 12 \\
\text { months }\end{array}$ & $\begin{array}{l}\text { - Good functional outcome at } 3 \text { months } 74.4 \% \text { vs } \\
49.2 \%(P<0.00 \mathrm{I}) \text { and } \mathrm{I} 2 \text { months } 75.9 \% \text { vs } 52.3 \% \\
(P<0.00 \mathrm{I}) \\
\text { - Outcomes maintained significance when } \\
\text { adjusted for risk factors and propensity score }\end{array}$ \\
\hline $\begin{array}{l}\text { Chen } \\
\text { et } \mathrm{al}^{37}\end{array}$ & $\begin{array}{l}\text { Retrospective } \\
\text { population- } \\
\text { based cohort } \\
\text { study }\end{array}$ & $\begin{array}{l}8,332 \\
\text { patients }\end{array}$ & $\begin{array}{l}\text { Statin therapy during } \\
\text { hospitalization or within } 3 \\
\text { months after discharge }\end{array}$ & $\begin{array}{l}\text { Recurrent ICH and } \\
\text { all-cause mortality }\end{array}$ & $\begin{array}{l}\text { - Adjusted hazard ratio for recurrent ICH } \\
\text { I.044 (95\% Cl: } 0.812-1.34 \mathrm{I}) \\
\text { - Adjusted hazard ration for all-cause mortality } \\
\quad 0.742(95 \% \mathrm{Cl}: 0.598-0.919)\end{array}$ \\
\hline $\begin{array}{l}\text { Dowlatshahi } \\
\text { et } \mathrm{al}^{29}\end{array}$ & $\begin{array}{l}\text { Retrospective } \\
\text { database analysis }\end{array}$ & $\begin{array}{l}2,466 \\
\text { patients }\end{array}$ & $\begin{array}{l}\text { Statin therapy prior to } \\
\text { admission and initiation } \\
\text { during hospitalization }\end{array}$ & $\begin{array}{l}\text { Severity of stroke } \\
\text { upon presentation, } \\
\text { mRS at discharge, } 30 \text { - } \\
\text { day mortality, 6-month } \\
\text { mortality }\end{array}$ & 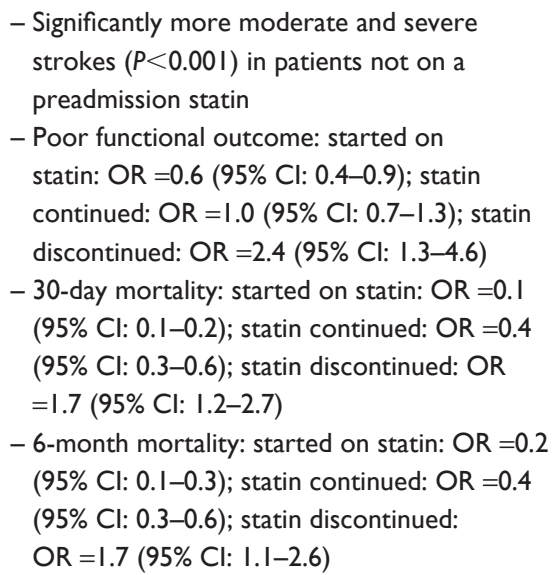 \\
\hline $\begin{array}{l}\text { Asberg et } \\
\mathrm{al}^{28}\end{array}$ & $\begin{array}{l}\text { Population- } \\
\text { based case- } \\
\text { control study }\end{array}$ & $\begin{array}{l}22,366 \\
\text { patients }\end{array}$ & $\begin{array}{l}\text { Statin therapy prior to } \\
\mathrm{ICH}\end{array}$ & $\begin{array}{l}\text { Multivariate regression } \\
\text { model }\end{array}$ & $\begin{array}{l}\text { - Unadjusted OR for ICH } 0.94 \text { (95\% Cl: } \\
\text { 0.87-I.02) } \\
\text { - Adjusted for concomitant drug use and } \\
\text { comorbid diseases OR for ICH } 0.68(95 \% \mathrm{Cl} \text { : } \\
\quad 0.63-0.74)\end{array}$ \\
\hline
\end{tabular}

Abbreviations: $\mathrm{Cl}$, confidence interval; ICH, intracerebral hemorrhage; OR, odds ratio; NIHSS, National Institutes of Health Stroke Scale; RCT, randomized controlled trial; RR, relative risk; SPARCL, Stroke Prevention by Aggressive Reduction in Cholesterol Levels; GCS, Glasgow Coma Scale; mRS, modified Rankin Scale; TIA, transient ischemic attack.

conclusive, it does suggest that initiation of statin therapy post-ICH may be reasonable in patients where the potential benefits outweigh the risks.

\section{Should statin therapy be discontinued immediately following $\mathrm{ICH}$ ?}

Statin discontinuation following ICH has been evaluated in several retrospective analyses. Discontinuation of statin therapy following $\mathrm{ICH}$ has been significantly associated with increased 30-day mortality (Table 2). ${ }^{29,35}$ Additionally, discontinuation of statin therapy following ICH was significantly associated with decreased favorable discharge when controlling for severity of illness and DNR (do not resuscitate) status. ${ }^{35}$ These outcomes should be viewed with caution because there are potentially significant confounders associated with discontinuation of statin therapy, namely, the withdrawal of aggressive management and transition to comfort care measures. Prospective trials are needed to adequately evaluate the effects of discontinuation of statin therapy in the setting of acute ICH. Until further evidence is generated, it appears reasonable to continue statin therapy in patients with $\mathrm{ICH}$ unless contraindications to therapy are noted.

\section{Effects of lipid levels on ICH}

As previously discussed, low serum lipid levels are a proposed mechanism for increased risk for ICH. Several clinical studies have sought to evaluate the relationship between plasma lipid level and incidence of $\mathrm{ICH}$. A retrospective multivariate analysis in 252 patients with ischemic stroke treated with tissue plasminogen activator showed no correlation with spontaneous $\mathrm{ICH}$ in patients on prior statin therapy despite patients having significantly lower serum LDL and total cholesterol levels. The study did find a significant association between increased serum triglyceride levels and increased spontaneous ICH. One significant limitation of this study is that lipid levels were only drawn 30 minutes prior to tissue plasminogen activator infusion and fasting lipid levels were 
not measured. ${ }^{39}$ A subsequent retrospective analysis of 381 patients with nontraumatic ICH evaluated risk factors, including statin use and serum lipid concentrations. This study also utilized admission serum lipid levels and did not report fasting levels. Additionally, LDL levels were calculated rather than directly measured serum concentrations. Hematoma volumes in the statin and nonstatin groups were 40.2 versus $16.9 \mathrm{~cm}^{3}$, respectively $(P<0.001)$. Total cholesterol and LDL were both inversely correlated with hematoma volume in both statin users and nonusers. The multivariate regression showed that serum total cholesterol levels $\leq 150 \mathrm{mg} / \mathrm{dL}$ were associated with statin use $(\mathrm{OR}=5.5,95 \% \mathrm{CI}$ : $1.55-19.58)$ and worsening of the National Institutes of Health Stroke Scale score $(\mathrm{OR}=1.4,95 \% \mathrm{CI}: 1.21-1.63)$ and hematoma volume (OR $=1.1,95 \%$ CI: 1.07-1.13) in ICH patients. An association was found among worsening of National Institutes of Health Stroke Scale score (OR =2.0, 95\% CI: 1.32-3.12), worsening of $\mathrm{mRS}$ score $(\mathrm{OR}=3.3,95 \% \mathrm{CI}$ : $1.33-8.00)$, hematoma volume $(\mathrm{OR}=1.3,95 \% \mathrm{CI}$ : $1.01-1.76)$, and serum total cholesterol levels $\leq 150 \mathrm{mg} / \mathrm{dL}$ in statin users. ${ }^{40} \mathrm{~A}$ more recent single-center retrospective analysis of $964 \mathrm{ICH}$ patients evaluated pre-ICH statin use and fasting serum lipid levels on $\mathrm{mRS}$ discharge and in-patient mortality. There was no significant difference in initial National Institutes of Health Stroke Scale, ICH volume, or intraventricular ICH location. Significantly lower total cholesterol and LDL cholesterol levels were observed in patients who died at 3 or 12 months. After adjusting for known ICH prognostic factors, LDL levels were independently associated with in-hospital mortality (OR $=0.54,95 \%$ CI: $0.31-0.93 ; P=0.028)$, but not 3 - and 6-month mortality. In contrast to the previously discussed study, there was no difference in mRS score at discharge, inhospital, and 3- and 12-month mortality between statin and nonstatin users. ${ }^{41}$ In summary, a potential increased risk of ICH may be present in patients with low LDL levels which appears to be independent of, but still potentially related to, statin use. Caution may be warranted if excessive lowering of LDL cholesterol is observed with statin therapy.

\section{Cerebral microbleeds}

Cerebral microbleeds (CMBs) are small foci of chronic blood products found in normal or nearly normal brain tissue. ${ }^{42}$ The population incidence of CMBs is $8.8 \%$ and increases with age. ${ }^{43}$ Hypertensive vasculopathy and cerebral amyloid angiopathy are two types of vascular pathologic changes in vessels associated with CMBs. CMBs are markers for risk of stroke, dementia, and cognitive impairment. ${ }^{42}$ The incidence of spontaneous conversion of $\mathrm{CMBs}$ to $\mathrm{ICH}$ is not well documented. ${ }^{44}$ One prospective observational study of ischemic stroke patients correlated increasing number of microbleeds to increased risk of subsequent ICH and increased mortality. ${ }^{45}$ The presence of CMBs in combination with antiplatelet, ${ }^{46}$ anticoagulant, ${ }^{46,47}$ intravenous thrombolytic therapy, ${ }^{48}$ and immunotherapy for Alzheimer's disease $^{49,50}$ increases the risk of ICH.

In a retrospective review of patients presenting with $\mathrm{ICH}$, patients on statin therapy were found to have a $19 \%$ $(P=0.039)$ higher prevalence of any CMB and a significantly increased mean number of CMBs per patient compared to patients not on statin therapy. This study also found a significant correlation between prior statin use and corticosubcortical microbleeds. ${ }^{51}$ Decreased LDL as the mechanism for increased CMBs has also been evaluated. In a study evaluating cholesterol levels, both low total cholesterol levels and high-density lipoproteins were independently associated with increased presence of multifocal signal loss lesions in patients undergoing magnetic resonance imaging due to neurologic abnormalities. ${ }^{52}$ Bang et al further evaluated the relationship among $\mathrm{ICH}, \mathrm{CMB}$, cholesterol, and statins. This retrospective evaluation of 102 ischemic stroke patients for hemorrhagic conversion following recanalization found no association between hemorrhagic conversion and statin use, but did find a significant correlation between lower LDL levels $(<85 \mathrm{mg} / \mathrm{dL})$ and increased hemorrhagic conversion. ${ }^{53}$ A prospective study of primary ICH patients not on statin therapy evaluated the effects of serum cholesterol on risk for primary ICH. This study found no significant correlation between low total serum cholesterol, LDL, or high serum high-density lipoprotein levels and ICH. However, the study did find an increased incidence of CMBs in patients with leukoaraiosis. ${ }^{54}$

Based on these studies, an attempt to isolate molecular markers predictive of CMBs has been pursued. A prospective observational cohort found no correlation between lipoprotein phospholipase A2 and CMBs but as a secondary outcome found a significant correlation between deep CMBs and patients with at least one apolipoprotein $\mathrm{E}$ (ApoE) $\varepsilon 2$ or $\varepsilon 4$ allele. ${ }^{55} \mathrm{~A}$ more recent study evaluated ApoE allele effects in combination with statin use for the risk of ICH. The study found no correlation between statin use or ApoE allele polymorphisms and increased risk of nonlobar ICH. However, patients on statin therapy with polymorphism ApoE $\varepsilon 4 / \varepsilon 4$ and $\varepsilon 4 / \varepsilon 2$ trended toward significance for increased risk of lobar ICH. ${ }^{56}$

$\mathrm{CMBs}$ are commonly present in patients requiring imaging of the brain secondary to neurologic changes. Increased 
numbers of $\mathrm{CMBs}$ correlate to poorer patient outcomes. Despite initial concerns, the body of evidence suggests that statins globally do not increase frequency or number of CMBs. Further studies with adequate power are necessary to illuminate specific patient populations (ie, genetic polymorphisms) where statins may increase the incidence of CMBs and $\mathrm{ICH}$.

\section{Discussion}

Statin use has been shown to reduce primary and secondary cardiovascular events, reduce coronary death rate, reduce total fatal and nonfatal stroke, and improve functional outcomes following an ischemic stroke. ${ }^{26,57-59}$ Statin therapy is currently widely used and is recommended for atherosclerotic cardiovascular disease risk reduction in broad patient populations. ${ }^{60,61}$ Despite the many benefits of statin therapy, there has been a signal toward increased rates of ICH with statin therapy. As discussed previously, data from the SPARCL trial showed a $16 \%$ decrease in total stroke, but a post hoc analysis showed a significant decrease in ischemic stroke events and an increase in $\mathrm{ICH}^{26,62}$

The mechanisms by which statin therapy may increase hemorrhage risk are unclear. A previous study described an inverse relationship to serum lipid levels and risk for $\mathrm{ICH}$ showing 6-year risk of death from intracranial hemorrhage was three times more likely in men with serum cholesterol levels less than $160 \mathrm{mg} / \mathrm{dL} .{ }^{63}$ Konishi et al proposed that decreased serum cholesterol levels contribute to the development of fragile cerebrovascular endothelium, eventually leading to the development of angionecrosis and cerebral hemorrhage in the setting of hypertension. ${ }^{64} \mathrm{~A}$ further proposed mechanism for an increased risk of $\mathrm{ICH}$ with statin therapy is the upregulation of platelet and endothelial nitric oxide synthase expression and platelet-derived nitric oxide release. These effects lead to decreased platelet-mediated arterial thrombosis which may be beneficial in preventing ischemic stroke but may be deleterious in ICH. ${ }^{65,66}$ Statins have also been shown to upregulate endogenous tissue plasminogen activator thus enhancing clot lysis and possibly placing a patient at higher risk for $\mathrm{ICH}^{67}$ These proposed mechanisms of increased risk for statin therapy in conjunction with increased ICH rates from the SPARCL trail have many clinicians more critically evaluating statin therapy in patients at risk for $\mathrm{ICH}$.

To date, there are no large prospective trials evaluating the safety and efficacy of statin therapy in ICH. Despite the retrospective signal for increased risk of $\mathrm{ICH}$ from the SPARCL trial, these findings were not further validated in several meta-analyses. The increased risk of ICH during treatment of statins could be due to patient characteristics. The SPARCL trial enrolled patients with prior ischemic stroke and these patients likely suffered microvascular injury secondary to their initial stroke. The combination of secondary microvascular injury and high dose atorvastatin therapy with lowered total cholesterol levels may have increased risk of ICH not seen in other prospective statin trials.

Further studies are needed to elucidate if there is a clinically relevant risk of decreased total cholesterol levels and development of ICH. Evaluation is also needed for specific patient cohorts who would benefit from statin continuation or discontinuation in relation to $\mathrm{ICH}$. In particular, the impact of statin therapy in older patients, men versus women, patients with specific comorbidities (eg, cardiovascular, diabetes), and those receiving a large number of concomitant or interacting medications may be important to analyze the effectiveness and risk for $\mathrm{ICH}$ in statin users. Given the paucity of clinical data providing clear direction on the use of statins in $\mathrm{ICH}$, careful evaluation of clinically relevant literature, evidencebased national guidelines, and patient risk versus benefit should be considered when utilizing statin therapy.

\section{Conclusion}

Statin therapy is widely used and recommended by multidisciplinary guidelines for primary and secondary prevention of arteriosclerotic cardiovascular disease and ischemic stroke prevention. Despite proposed pharmacologic mechanisms for increased risk of ICH and clinical findings from the post hoc analysis of the SPARCL trail, the increasing body of clinical evidence does not support the theory that statins significantly increase the rates of ICH. Decreased total cholesterol and LDL have mixed data for increased risk of $\mathrm{ICH}$, but this risk is not correlated with statin use. Further studies are required to delineate which $\mathrm{ICH}$ patients would benefit from statin therapy. Therefore, decisions regarding the use of statin therapy in patients with, or at risk for, ICH should be decided on an individual patient basis with statin therapy prescribed in situations where the potential to maximize benefits and minimize risk is greatest.

\section{Disclosure}

The authors report no conflicts of interest in this work.

\section{References}

1. Feigin VL, Lawes CM, Bennett DA, Barker-Collo SL, Parag V. Worldwide stroke incidence and early case fatality reported in 56 population-based studies: a systematic review. Lancet Neurol. 2009;8 355-369. 
2. van Asch CJ, Luitse MJ, Rinkel GJ, van der Tweel I, Algra A, Klijn CJ. Incidence, case fatality, and functional outcome of intracerebral haemorrhage over time, according to age, sex, and ethnic origin: a systematic review and meta-analysis. Lancet Neurol. 2010;9:167-176.

3. Qureshi AI, Tuhrim S, Broderick JP, Batjer HH, Hondo H, Hanley DF. Spontaneous intracerebral hemorrhage. N Engl J Med. 2001;344: 1450-1460.

4. Ariesen MJ, Claus SP, Rinkel GJ, Algra A. Risk factors for intracerebral hemorrhage in the general population: a systematic review. Stroke. 2003;34:2060-2065.

5. Brust JC. Clinical, radiological, and pathological aspects of cerebrovascular disease associated with drug abuse. Stroke. 1993;24:I129-I133.

6. Siniscalchi A, Bonci A, Mercuri NB, et al. Cocaine dependence and stroke: pathogenesis and management. Curr Neurovasc Res. 2015;12: 163-172.

7. Poon MT, Fonville AF, Al-Shahi Salman R. Long-term prognosis after intracerebral haemorrhage: systematic review and meta-analysis. J Neurol Psychiatry. 2014;85:660-667.

8. Schachter M. Chemical, pharmacokinetic and pharmacodynamic properties of statins: an update. Fundamental Clin Pharmacol. 2005;19: $117-125$.

9. McFarland AJ, Anoopkumar-Dukie S, Arora DS, et al. Molecular mechanisms underlying the effects of statins in the central nervous system. Int J Mol Sci. 2014;15:20607-20637.

10. Taylor F, Huffman MD, Macedo AF, et al. Statins for the primary prevention of cardiovascular disease. Cochrane Database Syst Rev. 2013;1:CD004816.

11. Willey JZ, Elkind MS. 3-Hydroxy-3-methylglutaryl-coenzyme A reductase inhibitors in the treatment of central nervous system diseases. Arch Neurol. 2010;67:1062-1067.

12. Mihos CG, Pineda AM, Santana O. Cardiovascular effects of statins, beyond lipid-lowering properties. Pharmacol Res. 2014;88:12-19.

13. Corsini A, Bellosta S, Baetta R, Fumagalli R, Paoletti R, Bernini F. New insights into the pharmacodynamic and pharmacokinetic properties of statins. Pharmacol Ther. 1999;84:413-428.

14. Wood WG, Eckert GP, Igbavboa U, Muller WE. Statins and neuroprotection: a prescription to move the field forward. Ann NY Acad Sci. 2010; 1199:69-76.

15. Johnson-Anuna LN, Eckert GP, Keller JH, et al. Chronic administration of statins alters multiple gene expression patterns in mouse cerebral cortex. J Pharmacol Exp Ther. 2005;312:786-793.

16. Thelen KM, Rentsch KM, Gutteck U, et al. Brain cholesterol synthesis in mice is affected by high dose of simvastatin but not of pravastatin. J Pharmacol Exp Ther. 2006;316:1146-1152.

17. Jones P, Kafonek S, Laurora I, Hunninghake D. Comparative dose efficacy study of atorvastatin versus simvastatin, pravastatin, lovastatin, and fluvastatin in patients with hypercholesterolemia (the CURVES study). Am J Cardiol. 1998;81:582-587.

18. Jones PH, Davidson MH, Stein EA, et al. Comparison of the efficacy and safety of rosuvastatin versus atorvastatin, simvastatin, and pravastatin across doses (STELLAR* Trial). Am J Cardiol. 2003;92: $152-160$.

19. Bays H. Statin safety: an overview and assessment of the data-2005. Am J Cardiol. 2006;97:6c-26c.

20. Kirkpatrick PJ, Turner CL, Smith C, Hutchinson PJ, Murray GD; STASH Collaborators. Simvastatin in aneurysmal subarachnoid haemorrhage (STASH): a multicentre randomised phase 3 trial. Lancet Neurol. 2014;13:666-675.

21. Latronico N, Bolton CF. Critical illness polyneuropathy and myopathy: a major cause of muscle weakness and paralysis. Lancet Neurol. 2011;10:931-941.

22. Pandit L, Agrawal A. Neuromuscular disorders in critical illness. Clin Neurol Neurosurg. 2006;108:621-627.

23. Schweickert WD, Hall J. ICU-acquired weakness. Chest. 2007;131: 1541-1549.

24. Gorson KC. Approach to neuromuscular disorders in the intensive care unit. Neurocrit care. 2005;3:195-212.
25. Bolego C, Baetta R, Bellosta S, Corsini A, Paoletti R. Safety considerations for statins. Curr Opin Lipidol. 2002;13:637-644.

26. Amarenco P, Bogousslavsky J, Callahan A, 3rd et al; The Stroke Prevention by Aggressive Reduction in Cholesterol Levels (SPARCL) Investigators. High-dose atorvastatin after stroke or transient ischemic attack. N Engl J Med. 2006;355:549-559.

27. Goldstein LB, Amarenco P, Zivin J, et al; Stroke Prevention by Aggressive Reduction in Cholesterol Levels Investigators. Statin treatment and stroke outcome in the Stroke Prevention by Aggressive Reduction in Cholesterol Levels (SPARCL) trial. Stroke. 2009;40:3526-3531.

28. Asberg S, Eriksson M. Statin therapy and the risk of intracerebral haemorrhage: a nationwide observational study. Int J Stroke. 2015: 46-49.

29. Dowlatshahi D, Demchuk AM, Fang J, Kapral MK, Sharma M, Smith EE; Registry of the Canadian Stroke Network. Association of statins and statin discontinuation with poor outcome and survival after intracerebral hemorrhage. Stroke. 2012;43:1518-1523.

30. Hackam DG, Woodward M, Newby LK, et al. Statins and intracerebral hemorrhage: collaborative systematic review and meta-analysis. Circulation. 2011;124:2233-2242

31. Jung JM, Choi JY, Kim HJ, Seo WK. Statin use in spontaneous intracerebral hemorrhage: a systematic review and meta-analysis. Int J Stroke. 2015:10-17.

32. Tapia Perez JH, Yildiz OC, Schneider T, Nimsky C. Meta-analysis of statin use for the acute therapy of spontaneous intracerebral hemorrhage. J Stroke Cerebrovasc Dis. 2015;24(11):2521-2526.

33. McKinney JS, Kostis WJ. Statin therapy and the risk of intracerebral hemorrhage: a meta-analysis of 31 randomized controlled trials. Stroke. 2012;43:2149-2156.

34. Steiner T, Al-Shahi Salman R, Beer R, et al. European Stroke Organisation (ESO) guidelines for the management of spontaneous intracerebral hemorrhage. Int J Stroke. 2014;9:840-855.

35. Flint AC, Conell C, Rao VA, et al. Effect of statin use during hospitalization for intracerebral hemorrhage on mortality and discharge disposition. JAMA Neurol. 2014;71:1364-1371.

36. Winkler J, Shoup JP, Czap A, et al. Long-term improvement in outcome after intracerebral hemorrhage in patients treated with statins. $J$ Stroke Cerebrovasc Dis. 2013;22:e541-e545.

37. Chen PS, Cheng CL, Chang YC, Kao Yang YH, Yeh PS, Li YH. Early statin therapy in patients with acute intracerebral hemorrhage without prior statin use. Eur J Neurol. 2015;22:773-780.

38. Pan YS, Jing J, Wang YL, et al. Use of statin during hospitalization improves the outcome after intracerebral hemorrhage. CNS Neurosci Ther. 2014;20:548-555.

39. Uyttenboogaart M, Koch MW, Koopman K, Vroomen PC, Luijckx GJ, De Keyser J. Lipid profile, statin use, and outcome after intravenous thrombolysis for acute ischaemic stroke. J Neurol. 2008;255:875-880.

40. Miura K, Yoshii Y, Nakamura Y, Ikeda K. Clinicoradiological profile and serum lipid levels of intracerebral hemorrhage in prior statin users. Intern Med. 2011;50:1385-1391.

41. Mustanoja S, Strbian D, Putaala J, et al. Association of prestroke statin use and lipid levels with outcome of intracerebral hemorrhage. Stroke. 2013;44:2330-2332.

42. Greenberg SM, Vernooij MW, Cordonnier C, et al. Cerebral microbleeds: a guide to detection and interpretation. Lancet Neurol. 2009;8: 165-174.

43. Romero JR, Preis SR, Beiser A, et al. Risk factors, stroke prevention treatments, and prevalence of cerebral microbleeds in the Framingham Heart Study. Stroke. 2014;45:1492-1494.

44. van Etten ES, Auriel E, Haley KE, et al. Incidence of symptomatic hemorrhage in patients with lobar microbleeds. Stroke. 2014;45: 2280-2285.

45. Soo YO, Yang SR, Lam WW, et al. Risk vs benefit of anti-thrombotic therapy in ischaemic stroke patients with cerebral microbleeds. J Neurol. 2008;255:1679-1686.

46. Vernooij MW, Haag MD, van der Lugt A, et al. Use of antithrombotic drugs and the presence of cerebral microbleeds: the Rotterdam Scan Study. Arch Neurol. 2009;66:714-720. 
47. Lee SH, Ryu WS, Roh JK. Cerebral microbleeds are a risk factor for warfarin-related intracerebral hemorrhage. Neurology. 2009;72: $171-176$

48. Dannenberg S, Scheitz JF, Rozanski M, et al. Number of cerebral microbleeds and risk of intracerebral hemorrhage after intravenous thrombolysis. Stroke. 2014;45:2900-2905.

49. Sperling R, Salloway S, Brooks DJ, et al. Amyloid-related imaging abnormalities in patients with Alzheimer's disease treated with bapineuzumab: a retrospective analysis. Lancet Neurol 2012;11:241-249.

50. Arrighi HM, Barakos J, Barkhof F, et al. Amyloid-related imaging abnormalities-haemosiderin (ARIA-H) in patients with Alzheimer's disease treated with bapineuzumab: a historical, prospective secondary analysis. J Neurol Neurosurg Psychiatry. 2016;87:106-112.

51. Haussen DC, Henninger N, Kumar S, Selim M. Statin use and microbleeds in patients with spontaneous intracerebral hemorrhage. Stroke. 2012;43:2677-2681

52. Lee SH, Bae HJ, Yoon BW, Kim H, Kim DE, Roh JK. Low concentration of serum total cholesterol is associated with multifocal signal loss lesions on gradient-echo magnetic resonance imaging: analysis of risk factors for multifocal signal loss lesions. Stroke. 2002;33:2845-2849.

53. Bang OY, Saver JL, Liebeskind DS, et al. Cholesterol level and symptomatic hemorrhagic transformation after ischemic stroke thrombolysis. Neurology. 2007;68:737-742.

54. Orken DN, Kenangil G, Uysal E, Gundogdu L, Erginoz E, Forta H. Lack of association between cerebral microbleeds and low serum cholesterol in patients with acute intracerebral hemorrhage. Clin Neurol Neurosurg. 2010;112:668-671.

55. Romero JR, Preis SR, Beiser AS, et al. Lipoprotein phospholipase A2 and cerebral microbleeds in the Framingham Heart Study. Stroke. 2012;43:3091-3094.

56. Woo D, Deka R, Falcone GJ, et al. Apolipoprotein E, statins, and risk of intracerebral hemorrhage. Stroke. 2013;44:3013-3017.

57. Ridker PM, Danielson E, Fonseca FA, et al. Rosuvastatin to prevent vascular events in men and women with elevated C-reactive protein. N Engl J Med. 2008;359:2195-2207.

58. Hong KS, Lee JS. Statins in acute ischemic stroke: a systematic review. J Stroke. 2015;17:282-301.
59. Heart Protection Study Collaborative Group. MRC/BHF Heart Protection Study of cholesterol lowering with simvastatin in 20,536 high-risk individuals: a randomised placebo-controlled trial. Lancet. 2002;360:7-22.

60. Stone NJ, Robinson JG, Lichtenstein AH, et al. 2013 ACC/AHA guideline on the treatment of blood cholesterol to reduce atherosclerotic cardiovascular risk in adults: a report of the American College of Cardiology/American Heart Association Task Force on Practice Guidelines. Circulation. 2014;129:S1-S45.

61. Kernan WN, Ovbiagele B, Black HR, et al. Guidelines for the prevention of stroke in patients with stroke and transient ischemic attack: a guideline for healthcare professionals from the American Heart Association/ American Stroke Association. Stroke. 2014;45:2160-2236.

62. Goldstein LB, Amarenco P, Szarek M, et al. Hemorrhagic stroke in the Stroke Prevention by Aggressive Reduction in Cholesterol Levels study. Neurology. 2008;70:2364-2370.

63. Iso H, Jacobs DR, Jr., Wentworth D, Neaton JD, Cohen JD. Serum cholesterol levels and six-year mortality from stroke in 350,977 men screened for the multiple risk factor intervention trial. $N$ Engl J Med. 1989;320:904-910.

64. Konishi M, Iso H, Komachi Y, et al. Associations of serum total cholesterol, different types of stroke, and stenosis distribution of cerebral arteries. Stroke. 1993;24:954-964.

65. Laufs U, Gertz K, Huang P, et al. Atorvastatin upregulates type III nitric oxide synthase in thrombocytes, decreases platelet activation, and protects from cerebral ischemia in normocholesterolemic mice. Stroke. 2000;31:2442-2449.

66. Yokoyama S, Ikeda H, Haramaki N, Yasukawa H, Katoh A, Imaizumi T. HMG-CoA reductase inhibitor protects against in vivo arterial thrombosis by augmenting platelet-derived nitric oxide release in rats. J Cardiovasc Pharmacol. 2005;45:375-381.

67. Asahi M, Huang Z, Thomas S, et al. Protective effects of statins involving both eNOS and tPA in focal cerebral ischemia. J Cereb Blood Flow Metab. 2005;25:722-729.
Vascular Health and Risk Management

\section{Publish your work in this journal}

Vascular Health and Risk Management is an international, peerreviewed journal of therapeutics and risk management, focusing on concise rapid reporting of clinical studies on the processes involved in the maintenance of vascular health; the monitoring, prevention and treatment of vascular disease and its sequelae; and the involvement of

\section{Dovepress}

metabolic disorders, particularly diabetes. This journal is indexed on PubMed Central and MedLine. The manuscript management system is completely online and includes a very quick and fair peer-review system, which is all easy to use. Visit http://www.dovepress.com/ testimonials.php to read real quotes from published authors. 